DOI: $10.1515 /$ rpp-2015-0024

PhD in Pedagogical Sciences, Associate Professor, VADYM CHYCHUK

Bogdan Khmelnytskyi Cherkasy National University, Ukraine Address: 81 Shevchenko Blvd., Cherkasy, 18031, Ukraine

E-mail: Chychuk.V@gmail.com

\title{
APPROACHES TO TRAINING TEACHERS OF ADULTS IN THE UK
}

\begin{abstract}
The article deals with the theoretical foundations of teacher training for adult students in the UK. It has been found out that the system of adult education is based on the andragogical approach that reveals patterns, psychological and pedagogical factors of effective learning. In applying the andragogical approach to adult education the following factors contribute to the learning process improvement: considering the motivation of adult learning, defining educational interests and needs of each adult student, the choice made by andragogue of the learning strategies and techniques designed to increase the professional level of adult education, practical implementation of knowledge and experience acquired by adult students in training process, taking into account the individual characteristics of each participant in the learning process, the desire to cooperate with the teacherandragogue. The theoretical basis of this process is the science of andragogics. It has been revealed that when working with an adult student, the following approaches are used: traditional didactic, problem-search, facilitating that are focused on the content and the learning process. Author determined specific approaches used in the UK for teaching adults, namely active, institutional, competence, synergy and others.
\end{abstract}

Key words: adult education, andragogics, teacher training, approaches, UK.

\section{INTRODUCTION}

Adult education is based on modern pedagogical and psychological approaches: modern society of the twenty-first century is characterized by rapid changes that are caused by internationalization, interpretation, the revolution in information and communication technology, modern technology. These processes lead to new challenges, changing roles and functions of teachers, formation of their personal characteristics as professionals. A special role in this process belongs to postgraduate educational establishments that will provide adequate practical requirements and willingness of teachers to work in the context of the following approaches: andragogical, proactive approach, competence, synergetic and others, i.e., patterns reflecting the pedagogical and psychological factors of effective adult learning (Овадюк, 2013).

\section{THE AIM OF THE STUDY} in the UK.

The aim of the research is to analyze the approaches used in teaching adults

\section{THEORETICAL FRAMEWORK AND RESEARCH METHODS}

Problems of andragogics as adult learning theory were studied by S. Arkhipova, M. Knowles, N. Protasova, L. Sigayeva; the peculiarities of adult learning are represented in the works of P. Jarvis, L. Lukyanova, N. Nychkalo, A. Rogers, L. Sigayeva and others. Adult education system is based on andragogical approach, revealing patterns, psychological and pedagogical factors of effective learning. The theoretical basis of this process is the science of andragogics (Овадюк, 2013). 
For realization of purpose research a complex of scientific research methods was used: analysis of philosophical, pedagogical, psychological, methodical literature for the ground of base positions of scientific search; interpretive and analytical method, on the basis of which the Ukrainian and foreign sources are analyzed with application of synthesis, analysis, systematization and generalization; comparative pedagogical methods which make possible to find out general and excellent signs in the content of preparation of adult teachers in Great Britain.

\section{RESULTS}

Andragogical approach allows to distinguish the methods of lifelong learning which motivate learning most of all, provide problem-reflexive nature, and contribute to the development of teachers' professional skills (Овадюк, 2013). Modern aspects of adult education are based on these leading positions of andragogical approach: the main role in education belongs to the adult student; training should take into account the individual characteristics of the student and promote their development; the process of adult education should be based on their desire for self-development; the studying process - is the cooperation of both students and those who teach (Овадюк, 2013).

As O. Ovadyuk and V. Burenko state, while using andragogical approach in adult education, the following factors contribute to the improvement of their learning: taking into account motivation of adult learning; defining educational interests and needs of each adult student; the choice by andragogue the learning strategies and techniques designed to increase professional level of adult education; practical application of knowledge and experiences acquired by adult students into studying process; taking into account the individual characteristics of each participant of learning process; the desire to cooperate with the teacher-andragogue (Буренко, 2009). As W. Lunyachek noted, the use of andragogical approach allows to adapt existing educational technology for teaching adults and thus to increase the effectiveness of training. An important condition for this process is the development of modern andragogical learning models (Лунячек, 2010).

Thus, the andragogical approach should be used in the system of adult education, because it is based on the knowledge about adult and takes into consideration his abilities, educational interests and life experience; its application makes it possible to adapt new educational technology to adults' training, which increases the effectiveness of their learning. Teacher acts as a facilitator and adult student psychology changes from being just a receiver of knowledge to the one who is ready to conscious education, to get his education in a creative way.

Theoretical Foundations of teachers' training for adult students education in the UK are represented by (P. Jarvis, M. Knowles, A. Rogers, P. Scales, M. Tight etc.) in scientific approaches, that scientists I. Takushyna grouped into the following directions: psychological, sociological and phenomenological (Такушина, 2011).

The psychological direction contains the following approaches: behavioural and psychoanalytic. Education accepted as the main factor in mental development of a person. Teacher's aim is, using psychoanalytic approach, create a conflict between old and new knowledge of adult students and assist them in solving the conflict. When using a behavioural approach teacher creates favorable conditions (climate, the system of interactions in the group) that promote changes in behaviour and mental functions of pupils.

Behavioral approach focuses on changing the behaviour of a person, not his mind. In the process of this approach realisation to training, teacher performs two main functions: watches the students for the purpose of predicting their behaviour; provides feedback to 
control their behaviour, encouraging the development of skills to perform certain actions (Шевчук, 2009).

Sociological direction combines humanistic, situational, social and cultural approaches. A. Rogers (Rogers, 1988), and other foreign scientists believe that when using the humanistic approach the main task of the teacher is to create and use a variety of learning situations where a teacher and adult students perform different roles, contributing to the development of the personality; situational approach contributes to the atmosphere of unity and cooperation in the group and constant progress, the teacher acts as a facilitator; social approach helps to change social reality through training; cultural approach takes into account the cultural, racial, religious and political affiliation of adult students, which helps to optimise adult education (Такушина, 2011). It may be noted that approaches which I. Takushyna combined in the sociological trend, are based on the fact that the teacher of an adult student should help him to determine his place in society.

Phenomenological direction includes constructivist, experiential and reflective approach, focusing on specific experience of the adult learner and its use in teaching. Proponents of this direction are foreign scientists, namely P. Jarvis, J. Rogers, P. Scales and others. The empirical approach is that human experience is seen as the foundation of the educational process and begins at the time when there is a discrepancy between previous experience and the new situation. This teacher should help adult learners to become aware of this contradiction and contribute to its solution. Constructivist approach helps teachers to teach adult students to reflect, analyze and transform the experience obtained in the new knowledge. Phenomenological direction combines the best ideas of the sociological and psychological directions, because it takes into account not only the external impact of socio-cultural environment, but also mental and physiological (internal) features of adult students, and therefore is the most effective direction in adult learning (Такушина, 2011).

Hence, the work of I. Takushyna (Такушина, 2011) states that in training teachers of adult students in the UK the following theoretical approaches are used and are grouped in three areas: phenomenological, sociological and psychological. Phenomenological appears to be the most promising in adult learning. But all these approaches focus on the specifics of adult education.

In the UK, while working with an adult student, the following approaches are also used: traditional didactic, problem-search, facilitating, which are aimed at the content and at the process itself. Let's briefly describe them.

Traditional didactic approach to adult education (focused on teacher) is used in adult education only when the teacher directs adult students to the analysis of material reported. Adult students will initiate the training that promotes better use of the material (Jarvis, 1995).

Problem-search approach is aimed at learning when adult students answer the teacher's questions using the knowledge (implicit), and previously acquired experience (Jarvis, 1995). Unlike traditional didactic approach, problem-search one has advantages: adult students acquire new knowledge using their own experience and they are active in the classroom (Топоркова, 1995). This approach is centered on the teacher because the teacher in class is important, but it is based on the experience and knowledge of students, although the teacher, as P. Jarvis noted, remains the central figure in class (Jarvis, 1995).

The approach focuses on the content (content-oriented) is an approach of selecting teaching methods based on content that is needed to be learned. This approach is increasingly centered on the teacher. The approach focused on the process is aimed at studying smaller amount of the material and at the usage of assimilation methods for further 
self-study of the material that is not learnt in class. This approach is centered on the adult student (Rogers, 1988).

The most promising for use in the further education of adults, according to British scientists A. Rogers, P. Jarvis, is facilitating approach centered on adult pupils, which involves the joint activity of a teacher and a student and using teaching methods based on this approach. Scientists say that the main task of the teacher is to help students to obtain knowledge (Rogers, 1988), i.e., training organization based on collaboration between facilitator and his student during the learning process.

As M. Tight noted (Tight, 1998), adult students are characterized by the significant life experience which should be used in the learning process through its analysis; teacher acts as a facilitator in the analysis of their experience. There is cooperation between a teacher and an adult learner. Only when there is a discrepancy between the previous experience and understanding of the adult learner and the arisen situation, there begins learning process, centered on the adult student. Moreover, as foreign scientists (M. Knowles, P. Jarvis, S. Brookfield) noted, adult students have their own motivation, which plays an important role in learning to achieve the goal.

According to O. Toporkova, brain parts that are responsible for the learning process, require constant activation for their successful operation. Therefore, participation in adult education programs contributes to the preservation and development of their abilities of thinking in general and training learning skills in particular (Топоркова, 2007).

So facilitating approach, centered on adult pupils, strengthens focus on students learning process, based on the fact that a teacher who acts as a facilitator creates a positive atmosphere for learning, helps to analyze past experiences of adult students, suggests cooperation between a teacher and a student, resulting in a mismatch between past experiences and an adult student understanding of the created situation, the teacher helps students to resolve such contradictions that emerged during training. We believe that this approach to adult education should be used in the development of the theory and practice of adult education. We believe that facilitating approach centered on adult pupils is the most promising to use for adults in Ukraine.

We have reviewed specific approaches used in the UK for teaching adults. Some didactic approaches, namely active, institutional, competence, synergy and others, can be also used.

Scientist T. Yakymovych uses activity and cognitive approaches in order to determine the quality of teacher training, his knowledge and skills level. As for the activity approach, the structure of activity is crucial (aim, motive, conditions, result) and skills relevant parameters: feasibility, effectiveness, efficiency. Approach, in which the parameters of knowledge and skills are related, the researcher defines as of knowledge (cognitive). Based on this approach, deep knowledge meet their production skills at the level of skills and abilities and also the following properties as awareness, versatility, generality and others are formed (Якимович, 2007).

As O. Bondarchuk states activity approach supersedes the general paradigm of education, which is reflected in the transition:

- from an isolated system of scientific concepts that make up the content of the subjects, to learning content in the context of solving vital duties (contextual learning);

- from individual learning to joint project activities;

- from passive consumers of knowledge to active subject of educational activity, which is "open" and takes possession of new activities (teaching, research, search, design, creative, etc.). Thus, the activity approach, according to the researcher, is the 
methodological basis on which the various systems of developing adult education as life subjects are built. (Бондарчук, 2014).

Thus, the activity approach to adult education contributes to actions, forecasting, reflection process, to the result of the activity. In the performance of their professional duties at the workplace they will implement this approach during the workflow.

As N. Boychenko states, institutional approach to adult education is one of the main approaches to provide adult students with necessary education. It provides means of institutional learning and corresponding theoretical approach that focuses on the study of these facilities. The institutional approach provides the public interest, subjecting it to group and personal interests. Institutional training requires a standardised curriculum, formally organised learning process, assessment standards of studying results (Бойченко, 2014).

To help adult students to exercise and develop skills, the teacher should have some competence. As T. Desiatov noted, in the process of adults' professional training within the competence approach the practical component of education should be focused, as it involves the need of knowledge in dealing with unusual situations in professional activities. From the standpoint of competency approach the adult education level should be determined by adult's ability to solve problems of various complexity based on knowledge and experience. When using the competency approach an adult must have professional competence that will help him to take his place in the modern labour market after the training process (Десятов, 2014).

We believe that providing competence approach in teachers' training of adult students is realized with the use of modern technology, the application of actions aimed at cooperation, self-improvement, self-realization.

Synergetic approach to adult education as N. Protasova noted is a methodological orientation of cognitive and practical activities in the field of adult education, which involves the use of ideas, concepts and methods in the study and management of adult education; it may be linear (the ability to exchange energy, matter, information with the environment), nonlinear (the presence of many random directions caused by internal or external random effects) and self-organised (self-organising system begins with chaos instability, when the existence of possible fluctuations - variations, deviations from the process that characterize the system. Characteristics of synergetic approach is the fact that there are alternative ways to develop systems that form the points of bifurcation (splitting) - choice of trajectory points (strategy) for further development, and that the future state of the system (like attractor attracts, creates, modifies existing state where attractors act as goal orientation in the development of adult education). The researcher drew attention to the importance of the synergistic approach in the management of adult education, as it takes into consideration natural self-organisation of subjects and objects in the interaction of managing and managed subsystems (Protasova, 2014).

\section{CONCLUSIONS}

Thus, in training of an adult teacher in the UK, the following approaches are used: andragogical approach (based on the knowledge of an adult with regard to his ability, educational interests and life experiences); synergistic approach to adult education (includes adult education management); competence approach (implemented using modern technologies); activity approach (encouraging an adult to act); facilitating approach (enhances the learning process towards students) and others.

The conducted research does not dip out all aspects of this actual problem. Further scientific search requires analysis of forms and methods of adults' studies in Great Britain. 


\section{REFERENCES}

1. Jarvis, P. (1995). Adult and Continuing Education: Theory and Practice. London : Routledge, p. 302.

2. Rogers, A. (1998). Teaching Adults. Buckingham and Philadelphia : Open University Press, p. 362.

3. Tight, M. (1998). Key Concepts in Adult Education and Training. London : Routledge, p. 196.

4. Бойченко, Н. М. (2014). Інституційний підхід в освіті дорослих [Institutional approach in adult education]. In: Кремень, В. Г., Ковбасюк, Ю. В. Освіта дорослих: енциклопедичний словник [Adult education: encyclopedic dictionary], p. 177. Київ : Основа (in Ukrainian).

5. Бондарчук, О. I. (2014). Діяльнісний підхід в освіті дорослих [Activity approach in adult education]. In: Кремень, В. Г., Ковбасюк, Ю. В. Освіта дорослих: енииклопедичний словник [Adult education: encyclopedic dictionary], p. 102. Київ : Основа (in Ukrainian).

6. Буренко, В. М. (2009). Як навчити дорослих? Удосконалення професійної підготовки вчителів на курсах підвищення кваліфікації на андрагогічних засадах [How to teach adults? Improving teacher training at the postgraduate courses based on andragogical principles]. In: Гуманітарні науки: науково практичний журнал [Humanities: scientific journal], No 2, p. 67-76 (in Ukrainian).

7. Десятов, Т. М. (2014). Компетентність у навчанні дорослих ослих [Competence in adult learning]. In: Кремень, В. Г., Ковбасюк, Ю. В. Освіта дорослих: енциклопедичний словник [Adult education: encyclopedic dictionary], p. 192-193. Київ : Основа (in Ukrainian).

8. Лунячек, В. (2010). Андрагогічний та акмеологічний підходи у підготовичі магістрів за спеціальністю "Державне управління» [Andragogical and acmeological approaches in training for Master's degree in "State Government"]. In: Нова педагогічна думка [New pedagogical ideas], No 4, p. 26-31 (in Ukrainian).

9. Овадюк, О. (2013). Аналіз андрагогічних підходів неперервного навчання дорослих у системі післядипломної педагогічної освіти [Analysis of andragogical approaches in adult lifelong learning system of Postgraduate Education]. In: Нова педагогічна думка [New pedagogical ideas], No 1, p. 117-122 (in Ukrainian).

10. Протасова, Н. Г. (2014). Синергетичний підхід в освіті дорослих [Synergetic approach in adult education]. In: Кремень, В. Г., Ковбасюк, Ю. В. Освіта дорослих: енииклопедичний словник [Adult education: encyclopedic dictionary], p. 387-388. Київ : Основа (in Ukrainian).

11. Такушина, И. А. (2011). Подготовка преподавателя дополнительного образования взросльх в Великобритании [Training lecturers of further adult education in UK]. Abstract of thesis for a Candidate's Degree in Pedagogical Sciences. Volgograd, p. 20 (in Russian).

12. Топоркова, О. В. (2007). Развитие дополнительного образования взрослых в Великобританиии [Development of further adult education in UK]. Thesis for a Candidate's Degree in Pedagogical Sciences. Volgograd, p. 179 (in Russian).

13. Шевчук, С. С. (2009). Інноваційні підходи до навчання професії: Методичний посібник [Innovative approaches to the teaching profession: Toolkit]. Донецьк : ІПО ІПП УМО АПН України, p. 117 (in Ukrainian).

14. Якимович, Т. Д. (2007). Як сформувати та оцінити інтелектуальні професійні вміння [How to form and evaluate intelligent professional skills]. In: Обдарована дитина [Gifted child], No 3, p. 2-8 (in Ukrainian). 